\title{
Lighting Quality and Visual Comfort Assesment in Working Environment
}

\begin{abstract}
The contribution deals with the evaluation of illumination of work in the manufacturing organization. The evaluation was performed by questionnaire survey and objectivised by measuring. The object of the investigation were all the staff who were willing to participate in an anonymous survey valuation visual comfort at your workplace. For the evaluation of the questionnaires were used basic statistical methods and evaluation methods of qualitative data.
\end{abstract}

Keywords: lighting, environment, visual comfort, color rendering index.

Úvod

Osvetlenie je dôležitý prvok pracovného prostredia, ktorý ovplyvňuje kvalitu, efektivitu, ale aj bezpečnost' práce. Hoci za posledné desat'ročie prešiel vývoj svietidiel a svetelných zdrojov určených na osvetl'ovanie pracovných priestorov výraznými zmenami, aj v súčasnosti sa nájdu budovy s technicky zastaranými svietidlami.

\section{Zraková pohoda}

Pri návrhu osvetl'ovacej sústavy pracoviska by malo byt' prioritou vytvorit' optimálne podmienky pre zrakový výkon v konkrétnom pracovnom prostredí tak, aby bola maximálne zabezpečená zraková pohoda. Aktuálna európska technická norma o osvetl'ovaní pracovných priestorov v interiéroch STN EN 12464-1, platná od marca 2012 , podporuje komplexné riešenia. Vzhl'adom na nové možnost svetelnej techniky norma síce niektoré požiadavky sprísnila, zároveň však platí, že predpísané hodnoty sa nevzt'ahujú na celý vnútorný priestor. Požadovaná intenzita osvetlenia, maximálne prípustné osInenie či optimálne podanie farieb svetelnými zdrojmi musia byt' dodržané pri jednotlivých druhoch pracovných prostredí špeciálne $v$ miestach zrakovej úlohy a v jej bezprostrednom okolí [1].

Zrakovú pohodu zabezpečuje optimálne osvetlenie priestoru. Zraková pohoda je psychologický stav, pri ktorom zrakový systém plní svoju funkciu optimálne. Vhodné osvetlenie je rozhodujúcim činitel'om, ovplyvňujúcim úroveň zrakovej pohody, ktorú ovplyvňuje typ svetelných zdrojov, druh a rozmiestnenie svietidiel, hladina osvetlenosti, rovnomernost' osvetlenosti v rôznych rovinách a rozloženie jasu v priestore. Dôležitú úlohu zohrávajú aj geometrické parametre priestoru a vlastnosti povrchov [2]. Graf svetelnej pohody vyjadruje potrebnú intenzitu osvetlenia pri danej teplote svetelného zdroja, tak aby sa svetlo javilo ako prirodzené, nie ako tmavé alebo príliš silné.

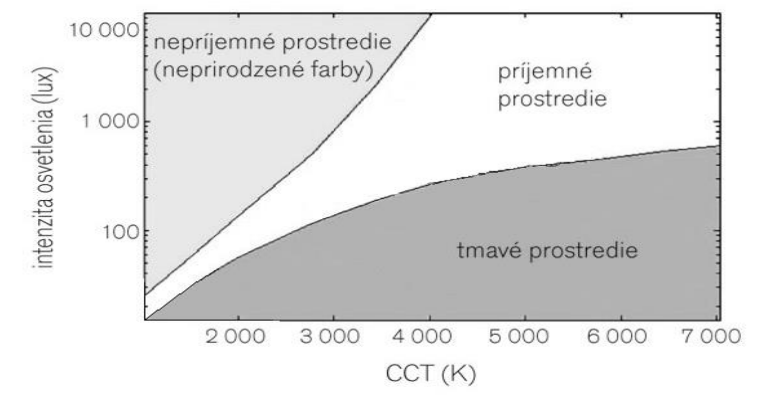

Obr. 1 Graf svetelnej pohody

Farba svetla

Pre dosiahnutie vhodného zrakového výkonu je dôležitá farba svetla a farebnost' povrchov. Vzt'ah farby svetla vychádzajúceho zo svetelného zdroja $k$ zdanlivej farbe vyžarovaného svetla sa vyjadruje tzv. teplotou chromatickosti, ktorá sa udáva v kelvinoch (K). Aby sa zabezpečila zraková pohoda, majú byt' na osvetlenie pracoviska použité svetelné zdroje s rovnakou farbou svetla. Výber je nutné prispôsobit' prostrediu. Ciel'om by malo byt', aby sa svetlo javilo čo najprirodzenejšie [3].

\section{Podanie farieb}

Pre objektívne posúdenie vlastností svetelných zdrojov z hl'adiska prirodzeného podania farieb sa používa index podania farieb $\mathrm{Ra}$ (CRI - color rendering index). Index podania farieb udáva mieru zhodnosti skutočnej farby povrchu predmetov s farbou pri osvetlení rôznymi zdrojmi svetla. Najvyšší index $\mathrm{Ra}$ na úrovni 100 má slnečné žiarenie. Index vyjadruje percentuálny podiel vinových dížok slnečného svetla $v$ umelom osvetlení. Parameter indexu podania farieb je menší pri svetelných zdrojoch $s$ menšou kvalitou podania farieb.

\section{Obmedzenie osInenia}

OsInenie je nepriaznivý stav zrakového vnímania. Vzniká vtedy, ked' je sietnica alebo jej čast' vystavená vyššiemu jasu, ako je ten, na ktorý je adaptovaná. Oko sa adaptuje na určitý priemerný jas zorného pola, ktorý ovplyvňuje všetky funkcie oka, teda aj pracovný výkon, kvalitu práce či únavu. Pri osInení dochádza k prerušeniu príjmu obrazových informácií prostredníctvom zraku. OsInenie $v$ interiéri nesmie prekročit' hodnoty stanovené pre danú kategóriu priestoru alebo vykonávanej činnosti normou Maximálne hodnoty osInenia, označovaného ako UGRL, sú uvedené v norme STN EN 12464-1.

\section{Intenzita osvetlenia}

Osvetlenost' alebo intenzita osvetlenia (E) je kvalitatívnou fyzikálnou veličinou, ktorá popisuje dosiahnutú úroveň osvetlenia. Je to podiel intenzity svetelného toku a osvetlenej plochy bez ohl'adu na odrazivost' tejto plochy. Udáva sa v luxoch (Ix). Plocha má osvetlenost' 1 lux, ak pri vel'kosti $1 \mathrm{~m}^{2}$ na ňu rovnomerne dopadá svetelný tok vel'kosti $1 \mathrm{~lm}$. Osvetlenost' klesá s kvadratickou závislost'ou od vzdialenosti svetelného zdroja. Osvetlenost' má vplyv na to, ako rýchlo, bezpečne a pohodlne vnímame a vykonávame potrebnú zrakovú úlohu. Priemerná hodnota osvetlenosti na pracovisku $v$ mieste zrakovej úlohy nesmie klesnút' pod normou stanovené hodnoty.

Osvetlenie pracovného prostredia priamo určuje priebeh pracovnej činnosti, kvalitu vykonávanej pracovnej činnosti, kvantitu vykonávanej pracovnej činnosti, psychickú pripravenost' pracovníka podat' čo najlepší výkon a psychický stav.

Nedostatočné osvetlenie môže byt' príčinou úrazov, chýb vo výrobe, napr. pri meraní. Pri osvetlení sa môže 
zbytočne plytvat' energiou a pri nesprávnom umiestnení svietidiel sa zbytočne namáha zrak. Dôležitost' osvetlenia sa prejavuje $v$ tom, že osvetlenie ovplyvňuje výkon a kvalitu práce, vznik úrazov a nehôd. $V$ prevádzkach so stálym umelým osvetlením musia byt' hodnoty osvetlenia v luxoch z psychologických dôvodov mnohonásobne prekročené, aby sa aspoň čiastočne kompenzovala potreba denného svetla.

\section{PInospektrálne osvetlenie}

Používanie plnospektrálnych svietidiel má priaznivé účinky na l'udský organizmus. Zmierňuje únavu zraku, podporuje zrakovú ostrost' a celkovú schopnost' vidiet'. Zvyšuje výkonnost' a produktivitu práce, zmierňuje pocit únavy a prispieva $\mathrm{k}$ lepšiemu sústredeniu sa. PInospektrálne svetlo umožňuje neskreslené vnímanie farieb a zmierňuje aj stres, obr.2.

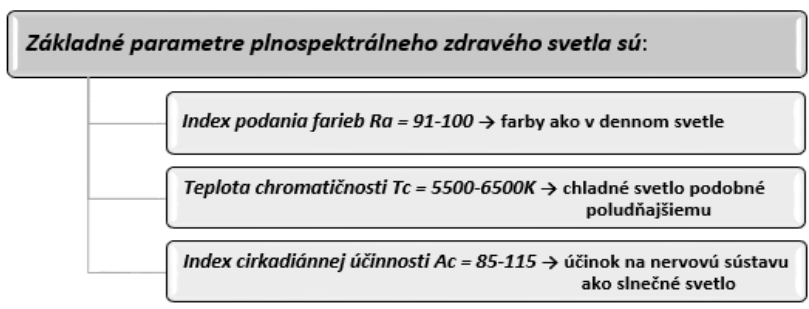

Obrázok 2. Parametre plnospektrálneho svetla

$\mathrm{V}$ značnej miere obmedzuje symptómy SAD [2,4]. PInospektrálne žiarovky, žiarivky a lampy poskytujú svetlo, ktroré sa podobá prirodzenému slnečnému svetlu, poskytuje farby denného svetla, zlepšuje ostrost' videnia, znižuje napätie a únavu $v$ očiach, odstraňuje symptómy SAD (zimné depresie), zvyšuje koncentráciu a produktivitu práce, zlepšuje zdravie, znižuje hyperaktivitu - ADHD a pod..Ďalšie výhody týchto zdrojov svetla sú ekologickost', vyššia životnost' a nižšie energetické náklady. V Nemecku a USA sa plnospektrálne osvetlenie používa už mnoho rokov a uskutočnil sa tam aj celý rad výskumov potvrdzujúcich jeho jedinečný vplyv na zrak, zdravotný stav i pracovnú výkonnost'. PInospektrálne svetlo pôsobí preventívne na viaceré problémy. Špeciálne simulátory slnečného svetla, ktoré majú dostatočný výkon (až 10000 luxov) môžu tieto problémy riešit' efektívne. Ideálna doba na terapiu je ráno hned' po prebudení. Pritom si môžeme čítat', či pracovat' na počítači, a pod. Účinnost' tejto fototerapie je až $80 \%$. Aj na Slovensku v Čechách sa robil výskum plnospektrálneho osvetlenia. Výsledky $v$ percentách boli pri používaní plnospektrálneho osvetlenia nasledovné:

- $70 \%$ účastníkov výskumu výrazne spríjemňuje pobyt na pracovisku,

- $60 \%$ trpí menšou únavou zraku,

- $58 \%$ lepšie vníma farby a farebné odtiene,

- $45 \%$ sa lepšie vie sústredit' a udáva zmiernenie únavy a podráždenosti,

- $38 \%$ má lepšiu náladu.

V súčasnosti sa dodáva široký sortiment kompaktných úsporných žiariviek s plnospektrálnym svetlom.

\section{Dotazníkový výskum}

Dotazník predstavuje jednu z najrozšírenejších metód získavania hromadných údajov, pomocou ktorých je možné analyzovat' subjektívne názory účastníkov vyjadrené $k$ danému problému.

Na skúmanie stavu vplyvu osvetlenia na výkonnost' a zdravie zamestnancov bola použíta subjektívna metóda hodnotenia, realizovaná prostredníctvom dotazníkového prieskumu vo vybranej organizácii. Firma je zameraná na šitie odevov, kde nároky na zrak sú pri pracovnej činnosti pomerne vysoké.

Výsledky a údaje $z$ dotazníka boli následne štatisticky spracované a vyhodnotené. Otázky boli kladené náhodným respondentom, ktorí pracovali $v$ hodnotenej firme a boli ochotní sa do prieskumu zapojit'. Do prieskumu sa zapojilo 105 respondentov z celkového počtu 320 zamestnancov skúmanej firmy. Prvá skupina otázok sa týkala zmapovania rušivých vplyvov osvetlenia pri výkone danej činnosti. Druhá skupina otázok poskytuje obraz o tom, aké subjektívne t'ažkosti vyvoláva osvetlenie u pracovníkov.

Dotazník obsahoval identifikačné údaje pre výber pohlavia, veku a dížky pracovného pomeru súbor a 21 uzavretých otázok, na ktoré bola nasledovná škála odvovedí: 1- nikdy, 2-občas/zriedkavo, 3-často, 4-vždy.

Najpočetnejšou vekovou kategóriou zo všetkých 105 respondentov bola skupina do 30 rokov - $44 \%$ a len $14 \%$ bolo vo veku nad 50 rokov, $61 \%$ bolo žien ( $39 \%$ mužov), dlžka pracovného pomeru do 5 rokov malo $51 \%$ dotazovaných, od 5 do 15 rokov $32 \%$, nad 15 rokov $17 \%$.

\section{Použité metódy riešenia}

Pomocou štatistickej metódy sme vykonali preverenie vzájomnej závislosti medzi troma vybranými údajmi významnými pre možné rozdelenie pracovníkov a vykonávanej pracovnej činnosti do kategórii. Preskúmali sme, či dané znaky sú zo štatistického hladiska významné, ako aj to, aká je miera ich závislosti. Vo väčšine prípadov bola zistená vel'mi silná závislost' medzi vybranými ukazovatel'mi.

Kontingenčné tabul'ky boli použité na vizualizáciu vzájomného vzt'ahu dvoch štatistických znakov. Riadky kontingenčnej tabul'ky zodpovedajú možným hodnotám prvého znaku, stlppe možným hodnotám druhého znaku. Pomocou kontingenčného grafu bol náslene vytvorený prehl'ad o týchto údajoch. Na testovanie bol použitý neparametrický Pearsonov test - Chí kvadrát.

Postup bol v nasledovných krokoch:

1. Zostavenie kontingenčných tabuliek a grafov, kde boli postavíme skúmané skupiny a ich zistené názory.

2. Zostavenie nulovej hypotézy $\mathrm{HO}$ a k nej alternatívnu hypotézu $\mathrm{Hn}$.

3. Určenie hraničnej hodnoty Chí-kvadrátu na zvolenej hladine významnosti.

4. Vypočet testovacieho kritéria, Chí-kvadrát podl'a vzt'ahu:

$$
\chi^{2}=\sum \frac{(O-E)^{2}}{E}
$$

5. Porovnanie vypočítanej hodnoty Chí-kvadrátu s tabul'kovou hodnotou Chí-kvadrátu na zvolenej hladine signifikancie.

6. Vyhodnotenie: Ak je vypočítaná hodnota nižšia než tabul'ková, nezamietame $\mathrm{H}_{0}$. Ak je naša hodnota Chí kvadrátu vyššia, než príslušná tabul'ková, $\mathrm{H}_{0}$ zamietame a prijímame alternatívnu hypotézu $\mathrm{Hn}$.

\section{Overenie závislosti medzi sledovanými znakmi}

Hodnotenie jednotlivých znakov $X$ a $Y$ (Tab.1), získaných $\mathrm{z}$ dotazníkov bolo spracované $\mathrm{v}$ kontingenčných tabul'kách a grafoch.

Table 1 Vybrané porovnávané znaky

Table 1 Vybrané porovnávané znaky
\begin{tabular}{|l|l|c|l|}
\hline \multicolumn{2}{|c|}{ Znak $X$} & \multicolumn{2}{|c|}{ Znak $Y$} \\
\hline$X_{1}$ & Vek & $Y_{1}$ & Pálenie, svrbenie a slzenie očí \\
$X_{2}$ & Dí̌za pracovného pomeru & $Y_{2}$ & Bolest' hlavy v dôsledku zrakovej námahy \\
$X_{3}$ & Náročnost' práce & $Y_{3}$ & Celková zraková únava \\
\hline
\end{tabular}


$\mathrm{Na}$ základe údajov $\mathrm{z}$ dotazníkového prieskumu bolo prevedené štatistické vyhodnotenie závislosti a miery významnosti sledovaných ukazovatel'ov. Boli skúmané hypotézy $\mathrm{Hn}$. Stanovené hypotézy boli testované prostredníctvom Pearsonovho Chí - kvadrátu testu nezávislosti a stupeň závislosti bol určený pomocou Cramerovho koeficientu, s použitím stupnice uvedenej v Tab.2.

Table 2. Stupne závislosti

\begin{tabular}{|c|c|}
\hline \multicolumn{2}{|c|}{ Hodnota koeficientov kontingencie } \\
\hline $0,1-0,3$ & slabá závislost' \\
\hline $0,3-0,5$ & stredne silná závislost' \\
\hline $0,5-0,8$ & silná závislost' \\
\hline$>0,8$ & velmi silná závislost' \\
\hline
\end{tabular}

Pri nulovej hypotéze $\mathrm{H}_{0}$ sa predpokladalo, že sledované znaky $\mathrm{X}$ a $\mathrm{Y}$ sú nezávislé.

Testované hypotézy Hn predpokladajú, že sledované znaky $\mathrm{X}$ a $Y$ sú závislé. Boli testované hypotézy Hn:

1. Hypotéza H1: Hodnotenie závislosti zrakových t'ažkostí

Yi od veku pracovníkov X1, tab. 3.

2. Hypotéza H2: Hodnotenie závislosti zrakových t'ažkostí Yi od dížky pracovného pomeru X2, tab.4.

3. Hypotéza H3: Hodnotenie závislosti zrakových t’ažkostí Yi od náročnosti vykonávanej práce $\mathrm{X} 3$, tab.5.

Table 3. Hodnotenie závislosti zrakových t’ažkostí od veku pracovníkov

\begin{tabular}{|c|c|c|c|c|c|c|}
\hline $\begin{array}{c}\text { Znaky } \\
x\end{array}$ & $X_{1}$ & Vek & $X_{1}$ & Vek & $X_{1}$ & Vek \\
\hline $\begin{array}{c}\text { Znaky } \\
Y\end{array}$ & $Y_{1}$ & $\begin{array}{c}\text { Pálenie, svrbenie } \\
\text { a slzenie očí }\end{array}$ & $Y_{2}$ & $\begin{array}{l}\text { Bolest hlavy v dôsl. } \\
\text { zrakovej námahy }\end{array}$ & $Y_{3}$ & $\begin{array}{c}\text { Celková zraková } \\
\text { únava }\end{array}$ \\
\hline $\begin{array}{c}\text { Testovacia } \\
\text { char. } \chi^{2}\end{array}$ & & 8,852 & & 8,320 & & 13,072 \\
\hline P-hodnota & & 0,031 & & 0,040 & & 0,004 \\
\hline Rozhodnutie & & Hozamietame & & Hozomietame & & Hozamietame \\
\hline Výsledok & & $\begin{array}{l}\text { ované znaky } X_{1} \text { a } Y_{1} \\
\text { sú závislé }\end{array}$ & & $\begin{array}{l}\text { dované znaky } X_{1} \text { a } Y_{2} \\
\text { sú závislé }\end{array}$ & & $\begin{array}{l}\text { dované znaky } X_{1} \text { a } Y_{3} \\
\text { sú závislé }\end{array}$ \\
\hline $\begin{array}{l}\text { Cramerov } \\
\text { koeficient }\end{array}$ & & $\begin{array}{l}863 \text { - velmi silná } \\
\text { závislost }\end{array}$ & & $\begin{array}{c}, 812 \text { - velmi silná } \\
\text { závislost }\end{array}$ & & $\begin{array}{l}1,275 \text { - vel'mi silná } \\
\text { závislost }\end{array}$ \\
\hline
\end{tabular}

Table 4. Hodnotenie závislosti zrakových t'ažkostí od dížky pracovného pomeru

\begin{tabular}{|c|c|c|c|c|c|c|}
\hline $\begin{array}{c}\text { Znaky } \\
X\end{array}$ & $x_{2}$ & $\begin{array}{l}\text { Dlíka pracovného } \\
\text { pomeru }\end{array}$ & $x_{2}$ & $\begin{array}{l}\text { Díżka pracovného } \\
\text { pomeru }\end{array}$ & $x_{2}$ & $\begin{array}{l}\text { Dižka pracovného } \\
\text { pomeru }\end{array}$ \\
\hline $\begin{array}{c}\text { Znaky } \\
Y\end{array}$ & $Y_{1}$ & $\begin{array}{c}\text { Pálenie, svrbenie } \\
\text { a slzenie oči }\end{array}$ & $Y_{2}$ & $\begin{array}{l}\text { Bolest' hlavy v dôsledku } \\
\text { zrakovej námahy }\end{array}$ & $Y_{3}$ & $\begin{array}{c}\text { Celková zraková } \\
\text { únava }\end{array}$ \\
\hline $\begin{array}{c}\text { Testovacia } \\
\text { char. } \chi^{2}\end{array}$ & & 3,848 & & 0,632 & & 11,851 \\
\hline P-hodnota & & 0,278 & & 0,889 & & 0,008 \\
\hline Rozhodnutie & & Honezamietame & & $\mathrm{H}_{0}$ nezamietame & & Hozamietame \\
\hline Výsledok & Slec & $\begin{array}{l}\text { ované znaky } X_{2} \text { a } Y_{1} \\
\text { nie sú závislé }\end{array}$ & & $\begin{array}{l}\text { ledované znaky } X_{2} \text { a } Y_{2} \\
\text { nie sú závislé }\end{array}$ & & $\begin{array}{l}\text { lované znaky } X_{2} \text { a } Y_{3} \\
\text { sú závislé }\end{array}$ \\
\hline $\begin{array}{l}\text { Cramerov } \\
\text { koeficient }\end{array}$ & & - & & - & & $\begin{array}{l}\text { 1,156 - vel'mi silná } \\
\text { závislost }\end{array}$ \\
\hline
\end{tabular}

Table 5. Hodnotenie závislosti zrakových t'ažkostí od náročnosti vykonávanej práce

\begin{tabular}{|c|c|c|c|c|c|c|}
\hline $\begin{array}{c}\text { Znaky } \\
X\end{array}$ & $X_{3}$ & Náročnost práce & $X_{3}$ & Náročnost práce & $X_{3}$ & Náročnost práce \\
\hline $\begin{array}{c}\text { Znaky } \\
Y\end{array}$ & $Y_{1}$ & $\begin{array}{c}\text { Pálenie, svrbenie } \\
\text { a slzenie oči }\end{array}$ & $Y_{2}$ & $\begin{array}{c}\text { Bolest hlavy v dôsl. } \\
\text { zrakovej námahy }\end{array}$ & $Y_{3}$ & $\begin{array}{c}\text { Celková zraková } \\
\text { únava }\end{array}$ \\
\hline $\begin{array}{c}\text { Testovacia } \\
\text { char. } \chi^{2}\end{array}$ & 8,666 & 5,081 & 8,146 \\
\hline P-hodnota & 0,034 & 0,166 & 0,042 \\
\hline Rozhodnutie & $H_{0}$ zamietame & Honezamietame & Hozamietame \\
\hline Výsledok & $\begin{array}{c}\text { Sledované znaky } X_{3} \text { a } Y_{15} \\
\text { sú závislé }\end{array}$ & $\begin{array}{c}\text { Sledované znaky } X_{3} \text { a } Y_{2} \\
\text { nie sú závislé }\end{array}$ & $\begin{array}{c}\text { Sledované znaky } X_{3} \text { a } Y_{3} \\
\text { sú závislé }\end{array}$ \\
\hline $\begin{array}{c}\text { Cramerov } \\
\text { koeficient }\end{array}$ & $\begin{array}{c}0,845 \text { - veĺmi silná } \\
\text { závislost }\end{array}$ & - & 0,794 - silná závislost \\
\hline
\end{tabular}

\section{Zhodnotenie}

Dotazníkovým prieskumom bolo zistené, že so stúpajúcim vekom pracovníkov a so zvyšovaním náročnosti práce stúpa pravdepodobnost' výskytu zrakových a psychicko-fyziologických problémov.

Hypotéza H1: Vplyv veku pracovníka na výskyt zdravotných problémov. V prípade hypotézy č. 1 sa potvrdila silná závislost'.

Hypotéza H2: Vplyv dížky pracovného pomeru na výskyt zrakových zdravotných t'ažkostí. V prípade hypotézy č. 2 sa potvrdila štatisticky významným len vzt'ah dížky pracovného pomeru a celkovej zrakovej úvany.

Hypotéza H3: Náročnost' práce mala silný až vel'mi silný vplyv na výskyt pálenia, svrbenia a slzenia očí, ako aj na celkovú zrakovú únavu.

Z výsledkov prieskumu vyplýva, že v danej organnizácii je potrebné odstránenie nedostatkov $v$ osvetlení a jeho zdokonalenie, čo je možné odhalit' napr. svetelnotechnickými auditmi. Dopad týchto objektívnych vplyvov sa dá zmiernit' aj osvetovou prácou zameranou na to, aby si pracovníci uvedomili súvislost' medzi zdravotnými problémami a osvetlením, dôležitost' odborného zdravotného posúdenia zraku a pod.

\section{Záver}

Človek vníma zrakom až $90 \%$ informácií a dobré osvetlenie bezprostredne súvisí ako $s$ bezpečnostou, bdelost'ou, výkonnost'ou, tak aj kvalitou a komfortom práce, $s$ pohodou aj záujmom o okolitý svet. Vplyv osvetlenia na výkon sa prejavuje $v$ tom, že ak zvýšime intenzitu osvetlenia, zaznamenávame stúpanie výkonu. Výsledky dlhoročných výskumov hovoria jednoznačne, že svetlo je vo vzt'ahu k celkovému zdraviu jedným $z$ najdôležitejších faktorov životného a pracovného prostredia.

Zdravé svetlo v zamestnaní pomáha zmiernit' únavu, zvýšit' výkonnost' a produktivitu, prispieva k ochrane zraku pri dlhodobej práci s počítačom, pozitívne ovplyvňuje stres na pracovisku a počet konfliktov medzi zamestnancami, vo výrobných halách prispieva k zniženiu úrazovosti a pod.

\section{Pod'akovanie}

Tento príspevok vznikol $v$ rámci riešenia projektu VEGA 1/0537/15 „Výskum vplyvu vybraných parametrov pracovného prostredia na pracovnú výkonnost' a produktivitu" (Research of influence of chosen parameters of working environment on working power and productivity).

\section{Literatúra}

[1] Dostál, F., Sokanský, K., Novák, T.: Long-term measurement of obtrusive light in campus VŠB-TUO, EPE 2009, VŠB-TUO, 60-62(2009), Czech republic, ISBN 978-80-248-1947-1

[2] Tyl,J.:Léto v zimě léčba světlem, Regena 2(2006), http://www.nastrojezdravia.sk/www/download.ph

[3] Walker, M.: The Power of Color,(1998), http://www.vitalight.com/articles/walker.htm

[4] Plch, J.: Svietidlá SAD, In: Svetlo 2005, Zborník zo 16. medzinárodnej konferencie, Jasná - Nízke Tatry, Bratislava, Typhoon, 261-268(2005), ISBN 80-969403-0-9.

[5] Králiková, R.: Lamps light therapy and influence of light on human, In: Transfer inovation, TUKE, Slovakia, 30 (2014), p. 245-248. ISSN 1337-7094.

Authors: doc. Ing. Ružena Králiková, PhD. ${ }^{1}$

Dr.h.c. prof. ing.Miroslav Badida, PhD.

${ }^{1}$ Technická Univerzita $v$ Košiciach, Strojnícka fakulta, Katedra procesného a environmentálneho inžinierstva, $P$. Komenského 5 , 04001 Košice, Slovensko.e-mail: ruzena.kralikova@tuke.sk miroslav.badida@tuke,sk

2Ing. Tomáš Konkoly, Magneti Marelli Slovakia, s.r.o, Kechnec, Slovakia, e-mail: tomas.konkoly@magnetimarelli.com 